\title{
INFLUENCE OF WASTEWATER ON ZOOPLANKTON COMMUNITY OF THE DAUGAVA RIVER AFTER DAUGAVPILS WASTEWATER TREATMENT PLANT MODERNIZATION
}

\author{
Rasma Deksne \\ Rezekne Higher Education Institution, Latgale Sustainable Development Research Institute \\ Atbrīvošanas aleja 76, Rezekne, LV 4601, Latvia, e-mail: rasma.deksne@ru.lv \\ Institute of Ecology, Daugavpils University, Vienības 13, Daugavpils, LV 5401, Latvia
}

\begin{abstract}
During seasonal studies 2010 (May-October, once/ thrice a month), samples of zooplankton were collected at the Daugava River section from $10 \mathrm{~km}$ upstream to $10 \mathrm{~km}$ downstream from the Daugavpils treatment plant wastewater discharge into the Daugava River. Changes in the quantitative and qualitative characteristics, saprobity index and species diversity (Shannon-Wiener index) were employed for the analysis of zooplankton community structure in the Daugava River. The Daugava River is polluted by Daugavpils wastewater, however the untoward influence of pollution on zooplankton is observed only in years and in seasons with low water level and discharge. The effect of Daugavpils wastewater pollution on changes in the zooplankton community is considered.
\end{abstract}

Keywords: hydrologic regime, large river, pollution, zooplankton.

\section{Introduction}

A number of authors (e.g. Bothár, 1988; Mulani et al., 2009; Gajbhiye \& Abidi, 1993) are indicating to the impact of wastewater on zooplankton. Potentiality of zooplankton as bioindicator is very high (Ferdous \& Muktadir, 2009; Lazareva, 2010; Escribano \& Hidalgo, 2000). A great number of authors are drawing attention to possibilities of the use of zooplankton for assessing the river water quality (Bakaeva \& Nikanorov, 2006; Vandish, 2000; Demenik, 1988; Kutikova, 1976; Krylov, 2005, 2006; Mathivanan et al., 2007; Vanjare, 2010; Mulani, 2009; Marneffe et al., 1996; Whitton, 1975).

Wastewaters from large cities, which are discharged into the Daugava River, are having their impact on ecosystems and populations of living organisms of the Daugava River (Auninšs, 1967; Matisone, 1965). The studies of 1950s and 60s on the Daugava River have shown that concentration of the dissolved substance and biogenic elements are tightly connected with the river water flow rate (Matisone, 1965). Laganovska (1963), Springige et al. (1999) concludes that impact of the Daugava River pollution on zooplankton can be observed at low discharge. Notable part of pollution flows into the Daugava River within the Daugavpils city administrative territory. According to the Central Statistical Bureau data, at the beginning of 2010 the city of Daugavpils has a population of 103.922. Before 2009 the Daugavpils wastewater treatment plant has operated using mechanical and biological purification, which does not ensure complete wastewater treatment. On 18 September 2009 the advanced Daugavpils city wastewater treatment plant was opened. After the project implementation the amount of phosphorus in wastewater has decreased nearly 5 times, which ensures compliance with the EU Directive (The Ministry of Environment, 2009).

Dynamics of the zooplankton population depends on chemical factors such as ammonium, nitrates, nitrites, phosphates (Marneffe, 1996; Deksne unpublished).

The aim of the following study is to establish influence of wastewater on zooplankton community of the Daugava River after Daugavpils wastewater treatment plant modernization. 


\section{Materials and methods}

During expeditions to the Krauja - Silupe stretch of the Daugava River (4 sampling sites) in 2010, zooplankton was sampled at the right and left banks, as well as in the middle of the river (Table 1). At this stage the river is relatively shallow, 2-4 m, with low current velocity of 0.1-0.2 $\mathrm{m} \mathrm{sek}^{-1}$.

Table 1.

GPS coordinates of the sampling sites and dates

\begin{tabular}{|c|c|c|c|}
\hline Sampling site & $\begin{array}{c}\text { Geographic } \\
\text { latitude }\end{array}$ & $\begin{array}{l}\text { Geographic } \\
\text { longitude }\end{array}$ & 2010 \\
\hline $\begin{array}{l}\text { No.16 Krauja (10 km } \\
\text { upstream from discharge of } \\
\text { the Daugavpils treatment } \\
\text { plant wastewater into the } \\
\text { Daugava River) }\end{array}$ & $55^{\circ} 54.787^{\prime} \mathrm{N}$ & $026^{\circ} 40.059^{\prime} \mathrm{E}$ & $\begin{array}{l}16 \text { May, } 2 \text { June, } 17 \text { June, } \\
1 \text { July, } 12 \text { July, } 30 \text { July, } \\
19 \text { August, } 30 \text { August, } 16 \\
\text { October, } 30 \text { October }\end{array}$ \\
\hline $\begin{array}{l}\text { Šunupe (place for discharge } \\
\text { of the Daugavpils treatment } \\
\text { plant wastewater into the } \\
\text { Daugava River) }\end{array}$ & $55^{\circ} 52.628^{\prime} \mathrm{N}$ & $026^{\circ} 30.093^{\prime} \mathrm{E}$ & $\begin{array}{l}17 \text { June, } 1 \text { July, } 12 \text { July, } \\
30 \text { July, } 19 \text { August, } 30 \\
\text { August, } 16 \text { October, } 30 \\
\text { October }\end{array}$ \\
\hline $\begin{array}{l}\text { Nr.17 } 1.5 \mathrm{~km} \text { downstream of } \\
\text { discharge of the Daugavpils } \\
\text { treatment plant wastewater } \\
\text { into the Daugava River) }\end{array}$ & $55^{\circ} 53.311^{\prime} \mathrm{N}$ & $026^{\circ} 28.401^{\prime} \mathrm{E}$ & \multirow{2}{*}{$\begin{array}{l}16 \text { May, } 2 \text { June, } 17 \text { June, } \\
1 \text { July, } 12 \text { July, } 30 \text { July, } \\
19 \text { August, } 30 \text { August, } 16 \\
\text { October, } 30 \text { October }\end{array}$} \\
\hline $\begin{array}{l}\text { Nr.18 Silupe }(10 \mathrm{~km} \\
\text { downstream of discharge of } \\
\text { the Daugavpils treatment } \\
\text { plant wastewater into the } \\
\text { Daugava River) }\end{array}$ & $55^{\circ} 57.322^{\prime} \mathrm{N}$ & $026^{\circ} 24.271^{\prime} \mathrm{E}$ & \\
\hline
\end{tabular}

Samples of zooplankton were collected by filtering 1001 of river water with the $65-\mu \mathrm{m}$ meshsized plankton net. Zooplankton individuals smaller than $65 \mu \mathrm{m}$ in size were not included in this research. Collected samples were fixed in $4 \%$ formalin. A Carl Zeiss light microscope was used for the analysis of zooplankton; three subsamples $(2 \mathrm{ml}$ each) were examined at 100-400 x magnification. The qualitative study was aimed at identification of the Rotifera, Cladocera and Copepoda taxa. All the zooplankton taxa were identified using keys of Kutikova (1970), Borutsky (1960), Manuilova (1964).

Water discharge data were obtained from the company "Latvian Environment, Geology and Meteorology Centre" database.

Species diversity was calculated according to the Shannon-Wiener index (Shannon, 1948; Krebs, 1999). The analysis of similarities across sites and years was carried out using the Renkonen index.

Saprobity index (S) was calculated according to Sladechek's method, using the species bioindicators' catalogue created by P.Cimdiņš for the Latvian conditions (Cimdiņš et al., 1995).

\section{Results and discussion}

During the 2010 studies, 71 taxa were found, among which there were 39 Rotifera, 23 Cladocera and 9 Copepoda taxa. $68 \%$ of the species found on the examined stretch of the Daugava River were indicator species of saprobity, which is a sufficient amount to consider the river pollution level according to zooplankton. Kutikova (1976) indicates that it is difficult to consider the river saprobity if there are few indicator species of saprobity in the river. 
During the 2010 research, the maximum discharge as $981 \mathrm{~m}^{3} \mathrm{~s}^{-1}$ was observed on 15 May, the minimum discharge as $131 \mathrm{~m}^{3} \mathrm{~s}^{-1}$ on 19 August. During the 2010 vegetation season when the upgraded Daugavpils wastewater purification plant was already operating, the negative impact of wastewater from Daugavpils on the zooplankton was evident in the form of zooplankton abundance decline at the wastewater influx site, established only at the lowest water level (85.05 m.a.s.1.) and flow rate on 19 August (Figure 1). With a slightly higher discharge (up to $\sim 280 \mathrm{~m}^{3} \mathrm{~s}^{-1}$ ) and water level (up to $\sim 85.55$ m.a.s.l.), decrease in numbers of zooplankton occurred $1.5 \mathrm{~km}$ downstream the place of wastewater discharge.

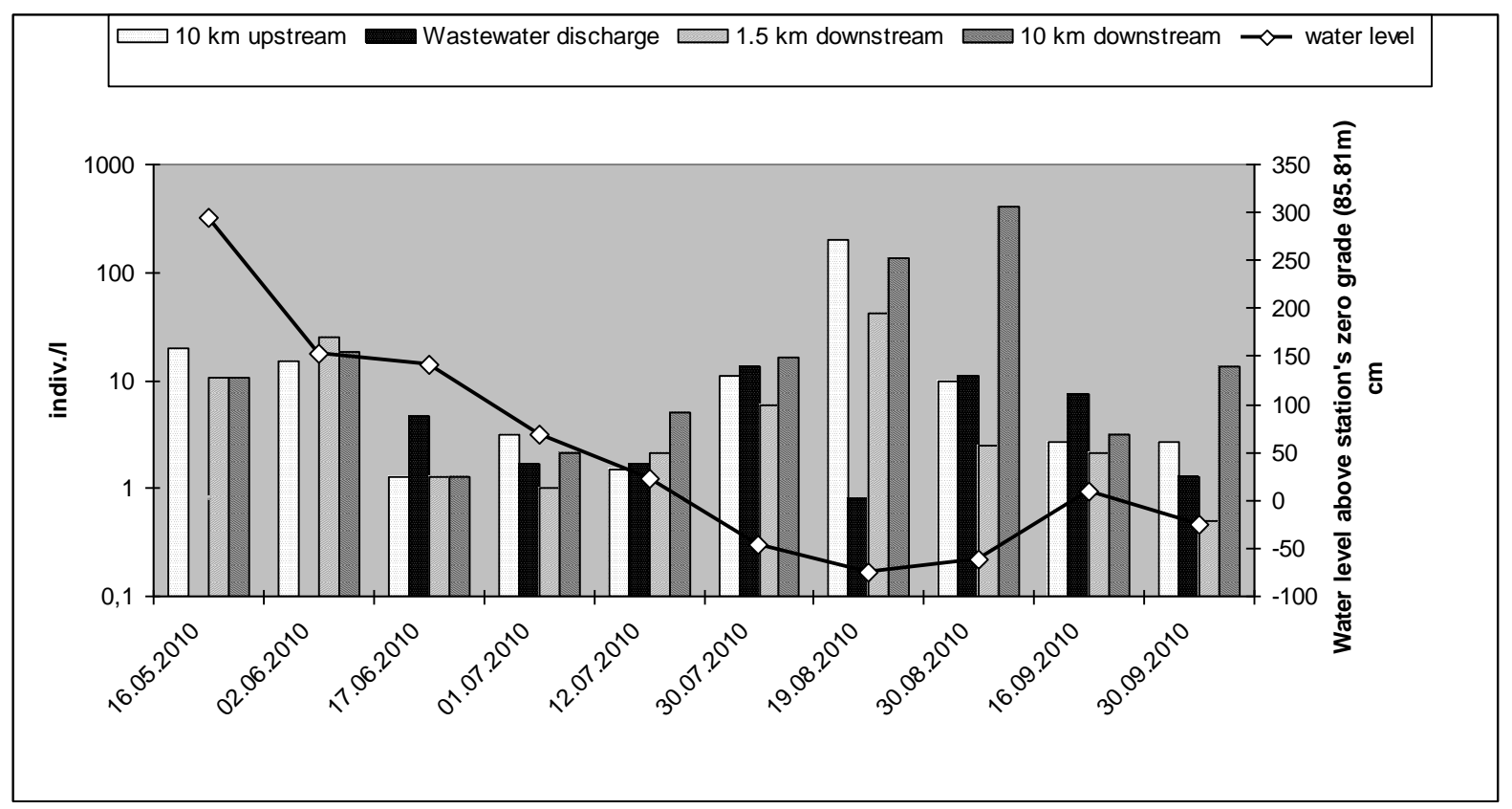

Fig. 1. Abundance of zooplankton and water level during the 2010 research

Similar conclusions when the number of zooplankton organisms in the Daugava River downstream of Daugavpils wastewater discharge decreased were made also in August 2008 at the water discharge $125 \mathrm{~m}^{3} \mathrm{~s}^{-1}$ (Figure 2).

An excessive inflow of biogenic substances into the river is having adverse effect on zooplankton expressed as reduction in terms of species diversity and increase of the Simpson's diversity index (Kononov, 2010). The given research at water level of 85.05 m.a.s.l. has observed reduction in numbers of taxa and the Shannon-Wiener index at the wastewater influx site. Number of taxa decreased from 23 to 2, the Shannon-Wiener index decreased from $7.510 \mathrm{~km}$ upstream from the Daugavpils wastewater influx site to 2.0 at the wastewater inflow site (Figure 3). When the water level is higher (up to $~ 85.55$ m.a.s.1.) in the same way as during the summer of 2008 , reduction in numbers of taxa and the ShannonWiener index is observed $1.5 \mathrm{~km}$ downstream from the wastewater influx site (Skutelis \& Deksne unpublished).

In 2010, 2009 and 1962 (Škute,1971), when the water discharge were exceeding $\sim 264 \mathrm{~m}^{3} \mathrm{~s}^{-1}$, water level was above 85.55 m.a.s.l., adverse effect of Daugavpils wastewater on the Daugava zooplankton cenoses was not evident (Figure 1, 2, 3, 4). 


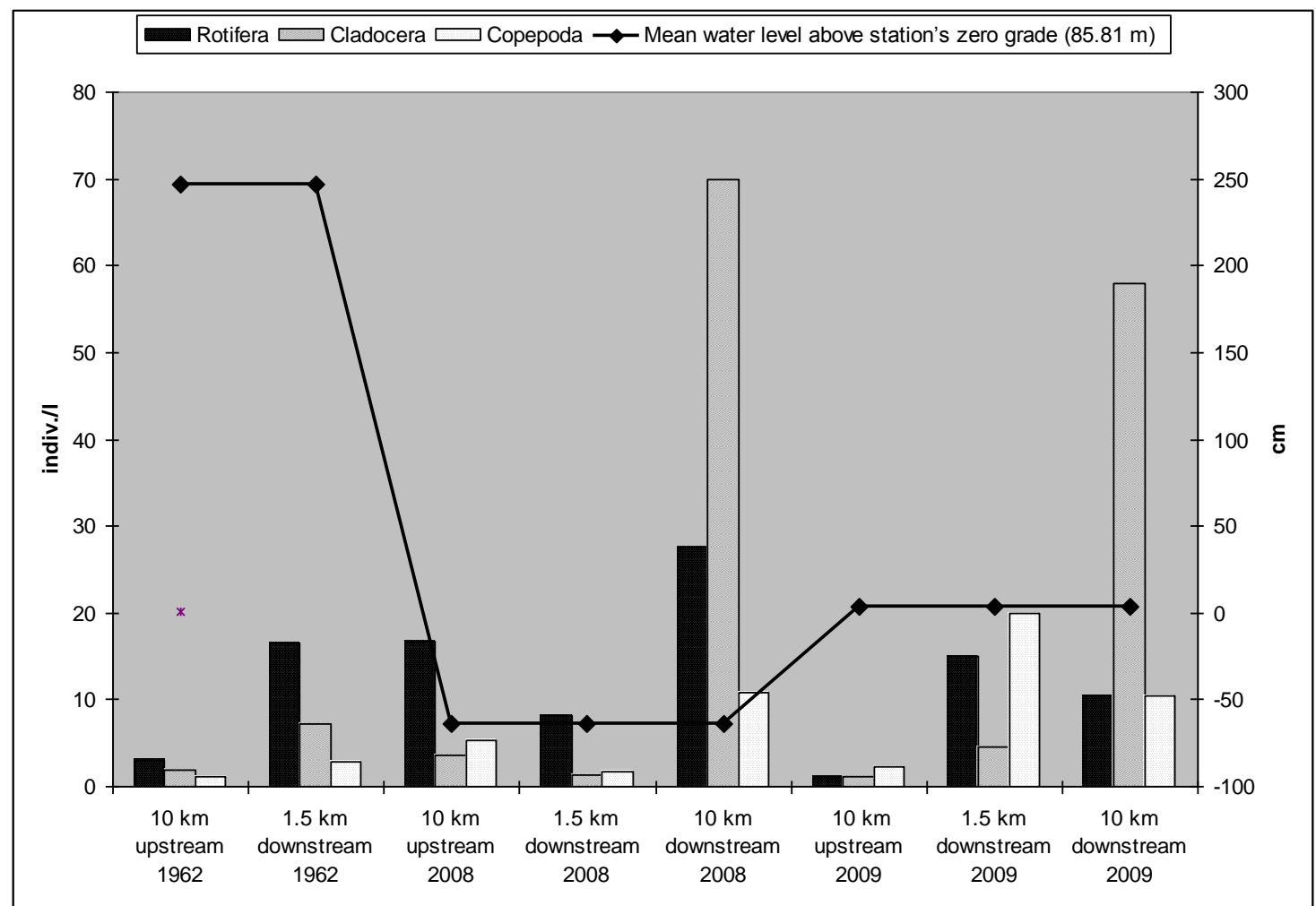

Fig. 2. Abundance of zooplankton and water level during summers of 1962, 2008 and 2009

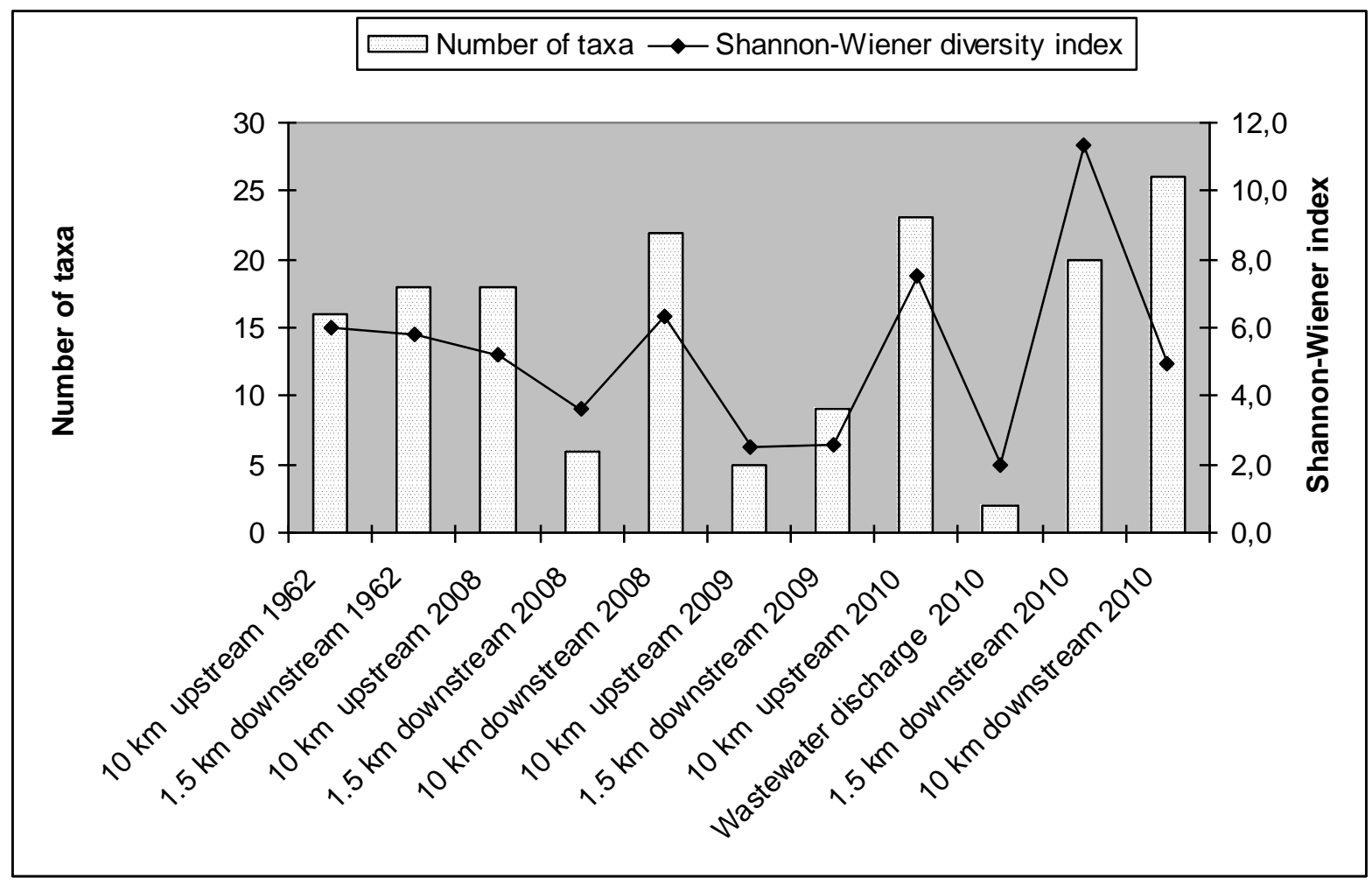

Fig. 3. Number of zooplankton taxa and the Shannon-Wiener diversity index during the summers of 1962, 2008 - 2010

In August 2010, like in the summer of 2008, reduction in the zooplankton abundance at the wastewater influx into the Daugava River and $1.5 \mathrm{~km}$ downstream from the Daugavpils 
wastewater influx site has occurred not only at the expense of dominant species, but also at the expense of reduction or even complete disappearance of the oligosaprobes, at the right bank none of the oligosaprobe species was found, while quantities of $\beta$ and $\alpha-\beta$ saprobe organisms increased (Figure 4). In August 2010 at the water level of 85.05 m.a.s.l. saprobity changed from o - saprobity, which describes a slight contamination $(\mathrm{S}=1.26)$ upstream of Daugavpils wastewater influx site to the $\beta$ - mezosaprobity, which describes a medium-level pollution $(S=2.2)$ at the wastewater influx site (Figure 4). At a higher water level (up to $\sim 85.55$ m.a.s.1.) increase of saprobity occurred $1.5 \mathrm{~km}$ downstream from the wastewater influx site (Skutelis \& Deksne unpublished).

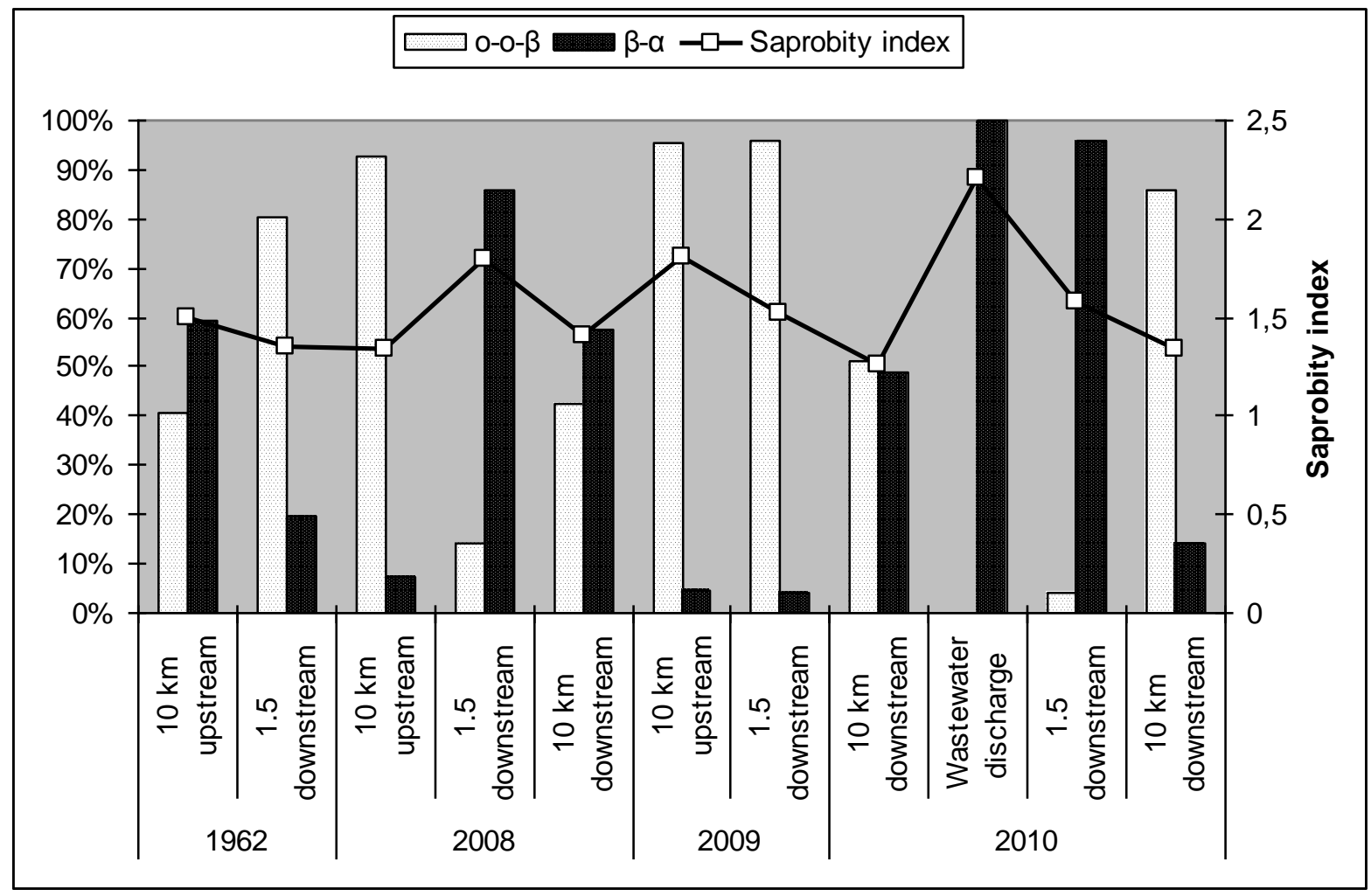

Fig. 4. Percentage distribution of the zooplankton abundance according to saprobity and saprobity index in the summers of 1962, 2008 - 2010

Zooplankton abundance and species diversity increased $10 \mathrm{~km}$ downstream from the Daugavpils wastewater influx site during all years and seasons (Figure 1, 2, 3). At high flow rates, which were observed in the summers of 1962 and 2009, and in the spring, autumn seasons of 2008 and 2010, zooplankton abundance and numbers of taxa increased just $1.5 \mathrm{~km}$ downstream from the Daugavpils wastewater influx site. Increase of zooplankton abundance and growth of diversity of species can be explained by the river self-purification processes, in this stretch of the river favorable wastewater dilution area is built up with richly developed bacteria plankton, which is very good feeding base for the development of zooplankton. Favorable condition for development of zooplankton downstream the Šunupe River is also greater depth of the river with relatively little less stream velocity. Several authors are reporting on the importance of zooplankton in the efficiency of self-cleaning processes (Kutikova, 1976; Bakaeva \& Nikonorov, 2006; Ivanova, 1976).

Upon comparison of the zooplankton cenoses on the right bank according to the Renkonen index $10 \mathrm{~km}$ upstream and $1.5 \mathrm{~km}$ downstream from the Daugavpils wastewater influx site, similarity between these sites was higher in $2009(72 \%)$ than in $2008(35 \%)$ and $2010(23 \%)$ when water levels and flow rates were low, therewith the wastewater dilution degree was low 
and the Daugavpils wastewater adversely affected the cenoses of zooplankton, thus changing the structure of zooplankton upstream and downstream the Daugavpils wastewater influx site (Table 2). When comparing the cenoses of zooplankton in 2008, 2009 and 2010 on the right bank $10 \mathrm{~km}$ upstream from the Daugavpils wastewater influx site, the similarity constitutes $58 \%, 49 \%$ and $47 \%$. While the similarity is lower when cenoses are compared $1.5 \mathrm{~km}$ downstream from the Daugavpils wastewater influx site, in 2008 and 2009 the similarity is $12 \%$ and in 2009 and in 2010 - 26\%. When comparing zooplankton cenoses at the same site in 2008 and in 2010 when under the impact of wastewater at low discharge changes in cenoses are taking place, the similarity was higher - 38\%. Consequently in 2008 and 2010 when there were low water levels and discharge, under the impact of wastewater there were more considerable changes in the zooplankton structure than in 2009 when the water level was high.

Table 2.

Establishment of similarity according to the Renkonen index

\begin{tabular}{|c|c|c|c|c|c|c|c|c|c|}
\hline & \multicolumn{2}{|c|}{2008} & \multicolumn{3}{|c|}{2009} & \multicolumn{3}{|c|}{2010} \\
\hline & & $\begin{array}{c}1.5 \mathrm{~km} \\
\mathrm{D} \\
\end{array}$ & $\begin{array}{c}10 \mathrm{~km} \\
\mathrm{D}\end{array}$ & $\begin{array}{c}10 \mathrm{~km} \\
\mathrm{U}\end{array}$ & $\begin{array}{c}1.5 \mathrm{~km} \\
\mathrm{D}\end{array}$ & $\begin{array}{c}10 \mathrm{~km} \\
\mathrm{D}\end{array}$ & $\begin{array}{c}10 \mathrm{~km} \\
\mathrm{U}\end{array}$ & $\begin{array}{c}1.5 \mathrm{~km} \\
\mathrm{D}\end{array}$ & $\begin{array}{c}10 \mathrm{~km} \\
\mathrm{D}\end{array}$ \\
\hline \multirow{3}{*}{$\stackrel{\infty}{\stackrel{\sim}{్}}$} & $10 \mathrm{~km} \mathrm{U}$ & 35 & 22 & 58 & 66 & 45 & 49 & 10 & 42 \\
\hline & $1.5 \mathrm{~km} \mathrm{D}$ & & 14 & 8 & 12 & 17 & 8 & 38 & 15 \\
\hline & $10 \mathrm{~km} \mathrm{D}$ & & & 10 & 33 & 43 & 50 & 19 & 43 \\
\hline \multirow{3}{*}{ } & $10 \mathrm{~km} \mathrm{U}$ & & & & 72 & 33 & 47 & 0 & 10 \\
\hline & $1.5 \mathrm{~km} \mathrm{D}$ & & & & & 58 & 33 & 26 & 13 \\
\hline & $10 \mathrm{~km} \mathrm{D}$ & & & & & & 12 & 9 & 46 \\
\hline \multirow{2}{*}{ 를 } & $10 \mathrm{~km} \mathrm{U}$ & & & & & & & 23 & 18 \\
\hline & $1.5 \mathrm{~km} \mathrm{D}$ & & & & & & & & 15 \\
\hline
\end{tabular}

$\mathrm{U}=$ upstream from discharge of the Daugavpils wastewater into the Daugava River;

$\mathrm{D}=$ downstream from discharge of the Daugavpils wastewater into the Daugava River.

However, it is recalled that the zooplankton dynamics depends not only on pollution and trophic status, but also on other factors (Гришанков \& Степанова, 2009; Deksne unpublished).

\section{Conclusions}

Daugavpils wastewaters pollute the Daugava River, however the adverse effects of pollution on zooplankton are exposed only in years and in seasons when water level $(<85.55$ m.a.B.s.1.) and discharge $\left(<264 \mathrm{~m}^{3} \mathrm{~s}^{-1}\right)$ is low. Also after modernization of the Daugavpils wastewater treatment plant the wastewater discharged into the Daugava River are affecting the zooplankton cenosis. The adverse effect of wastewater is expressed as decrease in the total abundance of zooplankton organisms, taxa and species diversity, increase of saprobity. 


\section{Acknowledgement}
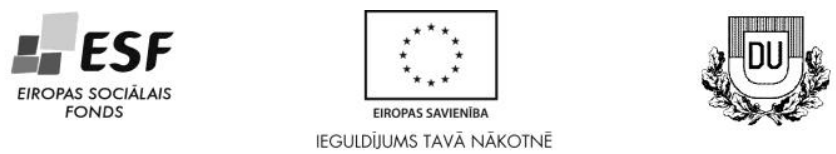

This work has been supported by the European Social Fund within the Project "Support for the implementation of doctoral studies at Daugavpils University" Agreement Nr. 2009/0140/1DP/1.1.2.1.2/09/IPIA/VIAA/015

\section{References}

1. Auniņš E. A., 1963. Calculation of ionic-salt run-off and the agrgression of water in the Daugava River. In: Kumsare A. J. (ed.), Hydrobiology and ichthyology of inland waterbodies in the Baltic states, Latvian SSR Academy of Sciences, Riga, 31-46. [Ауниньш Э.А., 1967. Расчёт ионно-солевого стока и агрессивности воды р. Даугавы. в кн.: А.Я. Кумсаре (Ред.).Гидробиология и ихтиология внутренних водоёмов Прибалтики. Рига: Тр. Ин-та биол. АН Латв. ССР, 31-46].

2. Bakaeva E. N. and Nikanorov A. M., 2006. Hydrobionts for the assessment of water quality, Institute of Water Problems, RAS, Nauka, Moscow, 239 р. [Бакаева Е. Н., Никаноров А. М., 2006. Гидробионты в оценке качества вод суши, Москва: Наука, 239 с.].

3. Bothár A., 1988. Results of long-term zooplankton investigations in the River Danube, Hungary. Verhandlung Internationale Vereinigung Limnologie., 23, 1340-1343.

4. Borutsky E. V., 1960. Key to identification of wild freshwater crawfish of the USSR and contiguous countries from fragments in fish intestines, Academy of Sciences of the USSR, Moscow, 218 p. [Боруцкий Е. В., 1960. Определитель свободноживущих пресноводных веслоногих раков СССР и сопредельных стран по фрагментам в кишечниках рыб. Москва: Изд-во АН СССР, 218 с.].

5. Cimdinsš P., Druvietis I., Liepa R., Parele E., Urtane L. and Urtans A., 1995. Latvian catalogue of indicator species of freshwater saprobity. Proceedings of the Latvian Academy of Sciences., 1/2, 122-133.

6. Demenik A.L., 1988. Turners as a component of zooplankton communities of rivers' ecosystems, VINITI, Minsk, 54 р. [Деменик А.Н., 1988. Коловратки как компонент сообщества зоопланктона речных экосистем. Деп. № 334-В88 (ВИНИТИ): Минск, 54 с.].

7. Escribano R. and Hidalgo P., 2000. Spatial distribution Spatial distribution of copepods in the north of the Humboldt Current region off Chile during coastal upwelling. Journal of the Marine Biological Association of the UK., 80, 283-290.

8. Ferdous Z. and Muktadir A.K.M., 2009. A Review: Potentiality of Zooplankton as Bioindicator. Applied Sciences, 6(10), 1815-1819.

9. Gajbhiye S.N. and Abidi S.A.H., 1993. Zooplankton distribution in the polluted environment around Bombay. Environmental Impact on Aquatic and Terrestrial Habitats, Ed. by: Agrawal, V.P., Abidi, S.A.H., Verma, G.P. 127-142p.

10. Ivanova M.B., 1976. Experience of participation of planktonic creatures in selfpurifying processes (on the example of zooplankton from the shores of the Izhora River). In: Skarlato O.A. (ed.), Hydrobilogical bases of water selfpurifying, Institute of Zoology, Leningrad, 36-42. [Иванова М. Б., 1976б. Опыт оценки участия планктонных животных в процессах самоочищения воды (на примере зоопланктона прибрежных учатков р. Ижоры). В кн: Гидробиологические основы самоочищения вод., Ленинград: Зоолог. институт АН СССР, 36-42].

11. Kononova O.N., 2010. Zooplankton of the Vichegda River tributaries with different degrees of anthropogenic load. Theses from Reports of the IV International Conference "Contemporary Problems of Hydroecology”, Saint Petersburg. 89 р. [Кононова О.Н. 2010., Зоопланктон притоков реки Вычегды с различной степенью антропогенной нагрузки. Тезизы докладов IV международной конференции “Современные проблемы гидроэкологии”, С.-Петербург. 89 с.]

12. Krebs J. C., 1999. Ecological Methodology. Second Edition, Addison Wesley Longman, Melno Park, California, USA, 620 p.

13. Krylov A. V., 2005. Zooplankton in plain rivers, Nauka, Moscow, 263 p. [Крылов, А. В. 2005. Зоопланктон равниных малых рек. Москва: Наука, 263 с.].

14. Krylov A.V., 2006. The changes in trophical structure of zooplankton water flow due to environmental factors. In: Rumjancev V.A. and Trifonova I.S. (eds), Report thesis in the International conference Bioindication in monitoring of freshwaters' ecosystems, St. Petersburg, 81-85 р. [Крылов, А. В., 2006. Изменения трофической структуры зоопланктона водотоков при влиянии ключевых факторов среды. Отв. ред. В.А. Румянцев, И.С. Тезисы докладов Международной конференции „Биоиндикация в мониторинге пресноводных экосистем” Спб., Санкт-Петербург, 81-85]. 
15. Kutikova L. A., 1970. Rotifera of the USSR fauna. Key to fauna of the USSR, Nauka, Leningrad, $744 \mathrm{p}$. [Кутикова Л. А., 1970. Коловратки фауны СССР. Определители по фауне СССР, издав. Зоол. Ин-том АН СССР. Вып. 104. Ленинград: Наука, 744 с. ].

16. Kutikova L.A., 1976. Water planktons' turners as the indicator of water quality. In: Kutikova L.A. (ed.), Methods of water biological analysis, Nauka, Leningrad, 80-90. [Кутикова Л.А., 1976. Коловратки речного планктона как показатели качества воды. $B$ кн. Кутикова Л.А., (Ред.). Методы биологического анализа пресных вод. Ленинград: Зоол. ин-т АН СССР, 80-90].

17. Laganovska R., 1963. Zooplankton of the river Daugava and peculiarities of its development in connection with hydrological regime and pollution of the river, 10th Freshwater in Baltic Scientific conference., Minsk, 139 р. [Лагановска Р.Я., 1963. Зоопланктон реки Даугавы и особенности его размешщения в зависимости от гидробиологическова режима и загрезнения реки. X Научная конференция по внутренним водоемам Прибалтики. Тез. Докл.: Минск, 139 с.].

18. Lazareva V.I., 2010. Zooplankton structure and Dynamics in the Rybinsk Reservoir, KMK Scientific Press Ltd., Moscow, 183 p. [Лазарева В.И., 2010. Структура и динамика зоопланктона Рыбинского водохранилища. М: Товарищество научных изданий КМК, 183 с.].

19. Latvian Environment, Geology and Meteorology Centre. Available from http://www.meteo.lv/public/ 27710.html (Accessed 12 April 2011).

20. Manuilova E. F., 1964. Cladocera of the USSR fauna, Nauka, Moscow-Leningrad, 327 р. [Мануйлова, Е. Ф. 1964. Ветвистоусые рачки (Cladocera) фауны СССР. Москва-Ленинград: Наука, 327 с.].

21. Marneffe Y., Descy J.P. and Thomé J.P. 1996. The zooplankton of the lower River Meuse, Belgium: Seasonal changes and impact of industrial and municipal discharges. Hydrobiologia., 319(1), 1-13.

22. Matisone M., 1965. Biogenic run-off of the Daugava River. In: Kumsare A. J. (ed.), Fishery of the inland warbodies in the Latvian SSR, Science, Riga, 365-379 p. [Матисоне М., 1965. Биогенный сток реки Даугава. В кн. А.Я. Кумсаре (Ред.), Рыбное хозяйство внутренних водоёмов Латвийской ССР. Рига: Зинатне, 365-379 с.].

23. Mathivanan V., Vijayan P., Sabhanayakam S., Jeyachitra O., 2007. An assessment of plankton population of Cauvery river with reference to pollution. Environ Biol., 28(2), 523-6.

24. Mulani S.K., Mule M.B.and Patil S.U., 2009. Studies on water quality and zooplankton community of the Panchganga river in Kolhapur city. Environ Biol., 30(3), 455-9.

25. Shannon C. E., 1948. Mathematical Theory of Communication. The Bell System Technical Journal., 27, 379-423,623-656.

26. Sprinǵe G., Sprinǵe G., Briede A., Druvietis I., Parele E., Rodinovs V. and Urtāne L., 1999. Investigations of biodiversity in freshwater ecosystems of Latvia. In: Naimovičiene Ž., Raudiene L., Virbickas T. (eds), Hydrobiological research in the Baltic countries. Part I. The rivers and lakes, Institute of Ecology, Vilnius, 232-272.

27. Škute R. J., 1971. Zooplankton of the River Daugava and its role in the productivity and biological evaluating of the river. Dissertation, Tartu University, Tartu, 233 р. [Шкуте, Р. Я. 1971. Зоопланктон реки Даугавы (кроме низовий) и его роль в продуктивности и санитарнобиологической оценке реки. Диссертация. Тарту. 233 с.]

28. The Ministry of Environment, 2009. available from http://www.vidm.gov.lv/lat/informacija_presei/ preses_relizes/?doc=954715.09.2009 (Accessed 17 December 2009).

29. Vandish O.I., 2000. Zooplankton as indicator of lake ecosystems' conditions (on the example of subartcical lake Imandra). Water resources., 27(3), 364-371. [Вандыш О.И., 2000. Зоопланктон как индикатор состояния озерных экосистем (на примере субарктического оз. Имандра). Водные ресурсы. 27(3), 364-371].

30. Vanjare A. I., Padhye S. M. and Pai K., 2010. Zooplankton from a polluted river, Mula (India), with record of Brachionus rubens (Ehrenberg, 1838) epizoic on Moina macrocopa (Straus, 1820). Opusc. Zool. Budapest., 41(1), 89-92.

31. Whitton B.A. (ed.), 1975. River Ecology. Studies in ecology, Volume 2, Blackwell Scientific Publications, US distributors: University of California Press, Berkeley, Oxford, 725 p.

Anotācija. Zooplanktona paraugi ievākti 2010. gada sezonālo (maijs-oktobris/ vienreiz līdz trīsreiz mēnesī) pētījumu laikā Daugavas upes posmā $10 \mathrm{~km}$ augšpus līdz $10 \mathrm{~km}$ lejpus Daugavpils attīrīšanas iekārtu notekūdeņu ieplūdes Daugavā. Daugavas zooplanktona cenožu struktūras analīzei izmantots to kvantitatīvais (organismu daudzums, taksonu skaits) un kvalitatīvais raksturojums, saprobitātes un Šenona-Vīnera daudzveidības indeksa izmaiņas. Daugavpils notekūdeņi piesārņo Daugavas upi, taču piesārņojuma nelabvēlīgā ietekme uz zooplanktonu parādās tikai gados un sezonās ar zemu ūdens caurplūdumu un lìmeni. Notekūdeņu nelabvēlìgā ietekme izpaužas kā kopējā zooplanktona organismu skaita, taksonu un sugu daudzveidības samazinājums, saprobitātes pieaugums. 